\title{
Determination of chemical composition of normal indigenous chickens in Malawi
}

\begin{abstract}
In Malawi, indigenous chickens are commonly kept by smallholder farmers and are raised under free range management system. However, no studies have looked at chemical composition of indigenous chicken meat. Hence, the objective of this study was to determine chemical composition of Malawian normal feathered indigenous chickens. The study was conducted at student's farm, Lilongwe University of Agriculture and Natural Resources (LUANAR). 71, 6 weeks, old normal feathered indigenous chickens were used and split into free range and intensive management systems. The chickens on free-range were supplemented with maize bran while those on intensive management system were given balanced ration $(17(\%) \mathrm{CP})$ throughout the experimental trial period. At 20, 24 and 28 weeks of age, 6 chickens (3cocks and 3 hens) were randomly selected for slaughter to determine the chemical composition

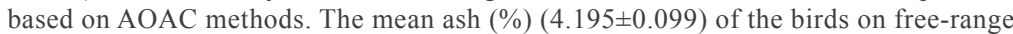
was significantly higher than those intensively managed $(3.699 \pm 0.099)(\mathrm{p}<0.05)$. The mean ash $(\%)(1.400 \pm 0.42)$ of birds on free-range was significantly higher that mean ash $(\%)(1.253 \pm 0.42)$ of birds intensively managed. Protein fat and moisture content were not affected by management system. Age affected the protein (\%) and Fat (\%). Chickens at 28 weeks had significantly high protein (\%) (21.958) than at 20 weeks $(20.045)(p<0.05)$. Fat $(\%)$ at 24 and 28 weeks was significantly higher than at 20 weeks. Sex did not affect the proximate chemical composition of the chicken meat. It is concluded that the best age to slaughter chickens is 24 weeks for optimal protein (\%) and relatively less fat.
\end{abstract}

Keywords: age, management system, protein, sex, protein
Volume 2 Issue 3 - 2017

William Pambuwa, Jonathan Tanganyika
Department of animal Science, Lilongwe University of
Agriculture and Natural Resources (LUANAR), Malawi

Correspondence: Jonathan Tanganyika, Animal Science Department, Lilongwe University of Agriculture and Natural Resources (LUANAR), Bunda campus, P.O. Box 219, Lilongwe, Malawi,Tel 265-993 494 774, Email jtanganyika@gmail.com, jtanganyika@bunda.luanar.mw

Received: July 12, 2017 | Published: October 10, 2017
Abbreviations: LUANAR, lilongwe university of agriculture and natural resources; CP, crude protein; GLM, general linear model

\section{Introduction}

Animal production in general and chickens in particular play important socioeconomic roles in developing countries. Small farming families, landless laborers and people with income below the poverty line are able to raise village chickens with low inputs and harvest the benefits of eggs and meat through scavenging feed resources. However, most communities lack the required husbandry skills, training and opportunity to effectively improve their chicken production. ${ }^{1}$ Despite the low productivity scavenging chickens still account for a major part of all meat produced in many developing countries where poultry is an important component of rural, peri-urban and urban households. ${ }^{2}$ In Malawi, most people who keep indigenous chickens are smallholder farmers and are found everywhere in the rural areas. Although the rearing of indigenous chicken is of significant importance in Malawi, there is paucity of information on chemical composition of IC. Consequently, slaughtering of the indigenous chickens is without the knowledge of their meat composition which poses a problem to come up with chickens of uniform chemical composition that can satisfy the consumers. However, to improve the chemical composition of indigenous chickens, baseline information must be known. Therefore, the present study seeks to provide baseline data which can be used by future improvement programmers of indigenous chickens in Malawi.

\section{Materials and methods}

\section{Experimental site and design}

The research was conducted at students' farm of Lilongwe
University of Agriculture and Natural Resources (LUANAR). 71 normal feathered indigenous chickens were used whereby 23 chickens were raised under intensive management system while 48 chickens were raised under free range management. On intensive management system, a ration containing $17 \%$ crude protein $(\mathrm{CP})$ was given to the experimental chickens from the start of the trial to the end. Birds on free range management were supplemented with maize bran in the morning before going for scavenging. The experiment used pullets of the same age (6 weeks old). Slaughtering was done at 20,24 and 28 weeks. At each slaughter age, 6 chickens were randomly selected (3 cocks and 3 hens) from each of the two management systems, for slaughter and the carcass analyzed for crude protein, crude fat, total ash and moisture.

\section{Data collection and carcass evaluation}

Before slaughter, the chickens were starved for 12 hours and slaughtering was done after stunning the birds using the pointed part of the knife by piercing it on the medulla oblongata of the chicken. After severing the neck, the birds were scalded using hot water. The skeletal muscle of each chicken was removed by the use of a knife, including the skin. The carcass was analyzed for chemical composition. This included moisture (\%), crude fat (\%), crude protein (\%), and ash (\%). The chemical determination was done on combination of the muscles and the skin of the chickens.

\section{Moisture determination}

The standard reference method for measurements of moisture in meat is oven drying (AOAC Method 950.46), ${ }^{3}$ In this experiment, fresh ground muscle by the use of food blender (about $4 \mathrm{~g}$ ) was dried in an oven at $105^{\circ} \mathrm{C}$ for 16 hours. Then after drying, the samples 
were re weighed. The difference between the weight of the undried meat and the dried was the moisture content of the meat. Moisture percentage was calculated using the formula bellow.

$$
\text { Moisture }(\%)=\frac{(x-y)}{x} \times 100
$$

Where: $\mathrm{X}=$ weight of undried meat sample and $\mathrm{Y}=$ weight of woven

$$
\text { Crude Protein }(\%)=(\%) \text { protein content }=
$$

Where N: Normality (0.01) of Standard HCL acid; V: Volume of standard HCL acid to titrate a sample; $\mathrm{V}_{\mathrm{b}}$ : Volume of standard HCL acid used to titrate a blank; W: Weight ( $\mathrm{g}$ ) of dry sample used; $\mathrm{D}=$ Dilution factor $(250 / 10)$.

\section{Crude fat determination}

Crude fat was determined by gravimetric measurement (AOAC Method 960.39) whereby 20g of ground and homogenized chicken meat, passed through $1 \mathrm{~mm}$ sieve were weighed and put into extraction thimbles and ether extraction followed by the use of Soxhlet apparatus/ extracts. Then the ether was evaporated from the extract (at $105^{\circ} \mathrm{C}$ ) and the remains were weighed. The crude fat (\%) was calculated using the formula bellow;

$$
\text { Crude Fat }=W(g)-Z(g) / W(g) * 100
$$

Where W (g): Weight of extraction thimble and sample before extraction;

$$
\text { Z: Weight of extraction thimble and sample after fat extraction. }
$$

\section{Ash determination}

In ash determination, $2 \mathrm{~g}$ of oven dried and ground muscle (passed through $1 \mathrm{~mm}$ sieve), dried at $100^{\circ} \mathrm{C}$, were weighed using a digital scale balance and then put in muffle furnace. The samples were incinerated at $550^{\circ} \mathrm{C}$ for 5 hours. The incinerated samples were weighed using digital scale balance. The ash was calculated using the formula below

$$
\operatorname{Ash}(\%)=\operatorname{CSD}(g)-\operatorname{CSA} / \operatorname{CSD}(g) * 100
$$

Where CSD: Weight (g) of crucible + sample before incineration Table I Effect of age on chemical composition dried meat sample.

\section{Crude protein determination}

This experiment used the Kjeldahl method (AOAC Method 976.05) which involved digestion of $2 \mathrm{~g}$ of ground meat samples (using a food blender), distillation, titration and calculating the crude protein by:

$\frac{\left[N \times 14.007 \times\left(V_{s}-V_{b}\right) \times 6.25 \times 250\right] \times D \times 100}{W \times 1000}$

CSA: Weight $(\mathrm{g})$ of crucible + sample after incineration

\section{Statistical analysis}

Data on chemical determination of the chicken meat was used to test the effects of management system, sex and age on chemical composition of the normal indigenous chickens. Data were analyzed using the General Linear Model (GLM) in SPSS. The parameters were analyzed using the model below

$$
Y_{i j k}=\mathfrak{A}+A_{i}+S_{j}+M_{k}+(\mathrm{AM})_{i k}+(\mathrm{SM})_{j k}+E_{i j k}
$$

Where $\mathrm{Y}_{\mathrm{ijk}}$ : Observed carcass characteristics on the individual chicken of the $\mathrm{k}^{\text {th }}$ management system; $\mathrm{j}^{\text {th }}$ sex and $\mathrm{i}^{\text {th }}$ age; $\mu$ : Overall mean of the observation; $A_{i}$ Effect of the $i^{\text {th }}$ Age; $S_{j}$ : Effect of the $j^{\text {th }}$ Sex; $\mathrm{M}_{\mathrm{k}}$ : Effect of the $\mathrm{k}^{\text {th }}$ Management system; $(\mathrm{MA})_{\mathrm{ik}}$ : Interaction of the $\mathrm{k}^{\text {th }}$ Management system and the $\mathrm{i}^{\text {th }}$ Age; $(\mathrm{SM})_{\mathrm{j} j}$ : Interaction of the $\mathrm{k}^{\text {th }}$ Management system and the $\mathrm{j}^{\text {th }} \mathrm{Sex} ; \mathrm{e}_{\mathrm{ijk}}$ : Random error component.

\section{Results}

\section{Effect of age on the chemical composition}

Table 1 shows the effect of age on chemical composition of IC. In this study, moisture was affected by age. Chickens slaughtered at 24 weeks and 28 weeks of age had a mean moisture content of $72.303 \pm 1.6487$ and $73.818 \pm 1.4769$, respectively. The mean moisture content of chickens slaughtered at 20 weeks old was not significantly different $(\mathrm{p}<0.05)$ from mean moisture content of chickens slaughtered at 24 and 28 weeks old. It was observed that the moisture content decreased from $73.063 \%$ to $72.303 \%$ and increased significantly at 28 weeks of slaughter age $(\mathrm{p}<0.05)$.

\begin{tabular}{llll}
\hline Variable & 20 Weeks & 24 Weeks & 28 Weeks \\
\hline Moisture(\%) & $73.063 \pm 2.1864^{\mathrm{ab}}$ & $72.303 \pm 1.6487^{\mathrm{ac}}$ & $73.818 \pm 1.4769^{\mathrm{b}}$ \\
Fat(\%) & $4.579 \pm 0.6324^{\mathrm{a}}$ & $5.1707 \pm 0.652 \mathrm{I}^{\mathrm{b}}$ & $5.046 \pm 0.4152^{\mathrm{b}}$ \\
Ash(\%) & $1.288 \pm 0.281^{\mathrm{a}^{\mathrm{a}}}$ & $1.296 \pm 0.2420^{\mathrm{a}}$ & $1.394 \pm 0.2456^{\mathrm{a}}$ \\
Protein(\%) & $20.045 \pm 0.2 .5922^{\mathrm{a}}$ & $21.314 \pm 2.3032^{\mathrm{ac}}$ & $21.958 \pm 1.6806^{\mathrm{bc}}$ \\
\hline
\end{tabular}

abc: Means on the same row with similar superscripts were significantly different at $\mathrm{P}<0.05$

NB: Fat, moisture, and protein were on fresh basis (raw chicken meat).

It was also observed that age affected fat content of the chickens, with chickens slaughtered at 24 and 28 weeks recording significantly higher fat content $(\mathrm{p}<0.05)$ than chickens slaughtered at 20 weeks of age. On the other hand, age did not have a significant effect $(\mathrm{p}<0.05)$ on ash content, however, it increased with increase in age of the chickens having recorded $1.288 \pm 0.2811,1.296 \pm 0.2420$, and $1.394 \pm 0.2456$ at 20, 24 and 28 weeks respectively (Table 1).

\section{Effect of sex on the chemical composition}

Table 2 shows the effects of sex on the composition of Moisture 
$(\%)$, Fat (\%), and Ash (\%). The results indicate that sex has no significant effect on chemical composition $(p<0.05)$. However, cocks had less moisture content $(73.060 \pm 0.290)$ as compared to hens (73.062 \pm 0.290$)$. It was also observed that hens had more fat content $(5.008 \pm 0.6150)$ than cocks $(4.856 \pm 0.6312)$. Hens also had more ash content $(1.333 \pm 0.042)$ than cocks $(1.320 \pm 0.042)$. Cocks, on the other hand, recorded a higher protein content $(21.306 \pm 2.3762)$ than hens (21.306 \pm 2.3762 vs 20.905 \pm 2.3084$)$ (Table 2).

Table 2 Effect of sex on the chemical composition

\begin{tabular}{lll} 
Variable & Cocks & Hens \\
\hline Moisture (\%) & $73.00 \pm 1.9633^{\mathrm{a}}$ & $72.668 \pm 1.815 \mathrm{I}^{\mathrm{a}}$ \\
Fat (\%) & $4.856 \pm 0.6312^{\mathrm{a}}$ & $5.008 \pm 0.6150^{\mathrm{a}}$ \\
Ash (\%) & $1.320 \pm 0.2694^{\mathrm{a}}$ & $1.330 \pm 0.2552^{\mathrm{a}}$ \\
Protein $(\%)$ & $21.306 \pm 2.3762^{\mathrm{a}}$ & $20.905 \pm 2.3084^{\mathrm{a}}$
\end{tabular}

a: Means with similar superscripts on the same row are not significantly different at 0.05 level of significance.

NB: Fat, ash and protein are on fresh basis (raw meat).

\section{Effect of management system on chemical composition}

Management system had no effect on chemical composition $(\mathrm{p}<0.05)$ in IC (Table 3). However, chickens on free-range had more moisture, fat and protein content of $73.455 \pm 2.0281,4.943 \pm 0.7176$ and $21.489 \pm 2.4797$, respectively. As compared to chickens raised on intensive management system $(72.668 \pm 1.6485,4.921 \pm 0.5234$ and $20.722 \pm 0.344$ ) for moisture, fat and protein content respectively. Overall, management system had a significant impact only on ash content of the chickens $(\mathrm{p}<0.05)$. The ash content $(1.400 \pm 0.2531)$ of chickens on free-range management system was significantly higher than $(1.253 \pm 0.2501)$ of birds on intensive management system (Table $3)$.

Table 3 Effect of management system on chemical composition of chickens

\begin{tabular}{lll}
\hline Moisture (\%) & $73.455 \pm 2.028 \mathrm{I}^{\mathrm{a}}$ & $72.668 \pm 1.6485^{\mathrm{a}}$ \\
Fat (\%) & $4.943 \pm 0.7176^{\mathrm{a}}$ & $4.921 \pm 0.5234^{\mathrm{a}}$ \\
Ash (\%) & $1.400 \pm 0.253 \mathrm{I}^{\mathrm{b}}$ & $1.253 \pm 0.250 \mathrm{I}^{\mathrm{a}}$ \\
Protein (\%) & $21.489 \pm 2.4797^{\mathrm{a}}$ & $20.722 \pm 2.1462^{\mathrm{a}}$
\end{tabular}

ab: Means on the same row with different superscripts were significantly different from each other at $p<0.05$.

\section{Discussion}

The results in Table 1 on moisture content agree with Wattanachant et al. ${ }^{4}$ and Wattanachant ${ }^{5}$ who reported a decrease in moisture content of Thai indigenous chickens during growth from 6 to 24 weeks. However, the results are not in line with Tougan et al. ${ }^{6}$ who reported that there was no change in moisture content of chickens from 20-24 weeks and then the moisture decreased at 28 weeks old. The results on moisture content also differ from findings by De Marchi et al. ${ }^{7}$ who reported no significant difference in dry matter content of meat from Padovana breed of chicken slaughtered at 150 and 180 days old. The differences can be attributed to the ecotype of the chickens. Some chicken ecotypes are fast growing and the chickens used in the current study are slow growing. The current results shows that fat content increased significantly with age from 20 to 24 weeks before decreasing slightly at 28 weeks of slaughter age. These observations are similar with those reported by Tougan et al. ${ }^{6}$ who reported significant increase in fat content of chickens slaughtered at 20, 24 and 28 weeks. The results are also in agreement with the findings of Diaz et al. ${ }^{8}$ who discovered a significant increase in total lipid content of chickens at 20 and 36 weeks old. Zanusso ${ }^{9}$ reported the similar results about breast and thigh muscles of chickens from 6 to 22 weeks. In the current study, the high fat content of chickens slaughtered at 24 weeks than at 28 weeks might be due to scarcity of feed during this period. Which led to the chickens relying on their body reserves for energy on different body metabolic processes. At this age, hens start laying and with the shortage of feed, they lose weight hence affecting their chemical composition. In the current study, sex had no significant effect on fat content of the Indigenous chicken. However, these results differ from those reported by Sunday et al. ${ }^{10}$ who observed that lipid content of chicken meat was higher in cocks than hens, whereas crude protein content was significantly higher in cocks than hens. On the other hand, findings from the current study on fat content are in line with the results reported by Abudullah \& Matarneh, ${ }^{11}$ who found no significant differences in chemical composition in broilers cocks and hens. On the other hand, Konrad \& Gaal ${ }^{12}$ found that sex had a significant effect only on ash content of thigh meat of yellow Hungarian cockerel $(0.98 \%)$ and pullets $(0.89 \%)$ raised on free-range for 84 days with high ash content recorded in pullets. The results in Table 3 showed that chickens on free-range system recorded high fat content than chickens on intensive system. The results differ from those reported by Tougan et al., ${ }^{6}$ who conducted a study to find out the effect of management system on nutrition quality of indigenous chickens, and found that the fat content of chicken meat from confinement was significantly higher than those chickens on freerange management system. These results on fat, protein and moisture content agree with reports by Fanatico et al. ${ }^{13}$ who revealed that breast moisture, fat, protein and ash content was not affected by production system. In the current study, rearing system (intensive and free range) did not affect the proximate composition of the chicken muscle. The high fat and protein content of the chickens on free-range may be due to the availability of feed in the proximity whereby chickens did not lose more energy searching for feed since it was rainy season. The chickens were scavenging around and even having some access to feed in the nearby pig units. Supplementation in the morning made the chickens less mobile as they would spend much of the time feeding on the supplement feed than scavenging. The season in which the study was conducted has also contributed to the results observed. The significant high ash content of the chickens on free range might be attributed to the season of the production. At the start of the rainy season, the grasses are tender and have relatively high mineral content. These grasses are liked by scavenging birds hence contributing to the high mineral content. The season is also characterised by snails, worms and small insects which contain remarkable high levels of minerals and might have contributed to the high ash content of the scavenging birds. The grass and the insects also contributed to the high fat content of the chickens on free-range since grass is digested by the chickens in the colon hence supplying energy which is usually stored as fat, ${ }^{6}$ however, there is a need to conduct a research to find out the effect of rearing season on the chemical composition of the Malawian indigenous chicken.

\section{Conclusion}

It can be concluded that management system, and age has significant effect on the chemical composition of the normal feathered indigenous chickens but sex has no effect on all the parameters analysed. The management system did not significantly, affect the 
fat and protein content of the normal feathered indigenous chickens, however the fat and protein was high for chickens on free-range management system. Sex did not affect the proximate composition of the normal feathered indigenous chickens, but cocks recorded high protein that hens and hens registered high fat content than cocks. Age had a significant impact on Moisture and Fat content of the normal indigenous chickens only, with chickens slaughtered at 24 and 28 weeks recording significant high fat content as compared to chickens slaughtered at 20 weeks of age.

\section{Acknowledgements}

The researcher would like to acknowledge the following people for material and intellectual support during the time of conducting the research project; InCIP personnel, Mr J Tanganyika (supervisor), Mr D Chiumia, Mr Chatepa, Mr Wilson Nandolo, Ms Chimwemwe Chigoma, and Ms Loveness Lundu.

\section{Conflicts of interest}

The author declares no conflicts of interest.

\section{References}

1. Mlozi MRS, Kakengi AVM, Minga UM, et al. Marketing of free range local chickens in Morogoro and Kilosa urban markets, Tanzania. Livestock Research for Rural Development. 2003:15(2).

2. Permin A, Petersen G. Problems related to poultry production at village level. Proceedings of the workshop on possibility of smallholder poultry projects in Eastern and Southern Africa. Southern Africa; 2000. p. 6569.

3. AOAC. Official methods of analysis. 7th ed. USA: In Association of Official Analytical Chemists; 2000. 25 p.

4. Wattanachant $\mathrm{S}$, Wattanachant C. Chemical composition, properties and microstructure of Thai indigenous chicken muscles as influenced by age and rearing systems. Thailand: Prince of Songkla University; 2007.
5. Wattanachant S. Factors affecting the quality characteristics of Thai indigenous chicken meat. Suranaree Journal of Science and Technology. 2008;15:317-322.

6. Tougan PU, Dahouda M, Salifou CA, et al. Nutritional quality of meat from local poultry population of Gallus gallus species of Benin. Journal of Animal \&Plant Sciences. 2013;19(2):2908-2922.

7. De Marchi M, Cassandro M, Lunard E, et al. Carcass characteristics and qualitative meat traits of Padovana breed of chicken. International Journal of Poultry Science. 2005;4(4):233-238.

8. Diaz OR, Torres A, Cobos A. Chemical composition and physicochemical properties of meat from capons as affected by breed and age. Spanish Journal of Agricultural Research. 2010;8(1):91-99.

9. Zanusso JT. Engraissement, structure des muscles et qualite de la vian de de volailles: example du gavage chez le canard de Barbarie (Cairina Moschata) et de la castration chez le poulet (Gallus domesticus). Tese (Doutorado emSciences de l'agriculture). France: Ecole Nationale Superieure Agronomique de Toulouse; 2002. 238 p.

10. Sunday OP, Olusegun MO, Brilliant OA, et al. Sex Effect on Gastrointestinal Nutrient Content, Microflora and Carcass Traits in Nigerian Native Chickens. International Journal of Poultry Science. 2010;9(8):731-737.

11. Abdullah AY, Matarneh SK. Broiler performance and the effects of carcass weight, broiler sex, and postchill carcass aging duration on breast fillet quality characteristics. J Appl Poult Res. 2010;19:46-58.

12. Konrad SZ, Gaal K. Effect of genotype, sex and keeping technology on the chemical compounds of breast and thigh meat of Hungrarian chickens. Hungary: University of West Hungary; 2009.

13. Fanatico AC, Cavitt LC, Pillai PB, et al. Evaluation of slower growing broiler genotypes grown with and without outdoor access. Poult Sci. 2005;84(11):1785-1790. 